\title{
Herpes simplex virus type II infection of ileum mesothelium: A case report and review of the literature
}

\author{
SAC Medlicott MD ${ }^{1}$, VG Falck MD ${ }^{1}, \mathrm{~KB}$ Laupland $M D^{2}, M$ Akbari MD ${ }^{1}$, PL Beck MD ${ }^{2}$
}

\begin{abstract}
SAC Medlicott, VG Falck, KB Laupland, et al. Herpes simplex virus type II infection of ileum mesothelium: A case report and review of the literature. Can J Gastroenterol 2005;19(6):367-371.

Disseminated herpes simplex virus (HSV) infection usually manifests in the immunocompromised. However, anecdotal examples of visceral HSV disease and viremia have complicated type I diabetes.

A case of a 53-year-old type I diabetic patient with bowel obstruction one week subsequent to bronchitis is reported. At laparotomy, a perforated segment of ileum was associated with an adhesive peritoneal band. HSV cytopathic atypia and HSV immunohistochemical staining were confined to fibrocytes and mesothelial cells without involvement of the epithelium. Dissemination of symptomatic HSV pneumonia was verified by histology, immunohistochemistry, in situ hybridization, polymerase chain reaction and direct fluorescence antibody. Intravenous acyclovir resolved symptoms.

This is a novel documentation of HSV complicating ileal adhesive band disease. Furthermore, this case indicates that the HSV cytopathic effect is not unique to the epithelium. Disseminated infection can manifest in myofibrocytes and mesothelium, distinguishing it from standard epithelial atypia of localized HSV infection.
\end{abstract}

Key Words: Adhesive band disease; HSV; Mesothelium

\section{Infection au virus de l'herpès simplex de type II du mésothélium iléal : Rapport de cas et revue de la littérature}

L'infection au virus de l'herpès simplex (HSV) disséminé se manifeste habituellement chez les sujets immunodéficients. Des cas isolés de maladie viscérale et de virémie au HSV ont par contre compliqué certains cas de diabète de type $\mathrm{I}$.

On présente ici le cas d'un patient de 53 ans atteint de diabète de type I ayant souffert d'une obstruction intestinale pendant une semaine à la suite d'une bronchite. À la laparotomie, un segment perforé de l'iléon a été associé à des adhésions péritonéales en bandes. L'atypie cytopathologique et le HSV confirmé par coloration immunohistochimique étaient confinés aux fibrocytes et aux cellules mésothéliales, sans atteinte de l'épithélium. La dissémination de la pneumonie symptomatique à HSV a été vérifiée au moyen de tests histologiques, immunohistochimiques, par hybridation in situ, réaction en chaîne de la polymérase et mesure directe des anticorps à l'immunofluorescence. De l'acyclovir par voie intraveineuse est venu à bout des symptômes.

Il s'agit d'un nouveau cas documenté de HSV compliquant des adhésions iléales. En outre, ce cas indique que l'effet cytopathologique du HSV ne se limite pas à l'épithélium. L'infection disséminée peut se manifester dans les myofibrocytes et le mésothélium, en quoi elle se distingue de l'atypie épithéliale associée à l'infection localisée au HSV.
Gastrointestinal herpes simplex virus (HSV) infection is J predominantly a disease of the esophagus in immunodeficient patients. Patients are usually asymptomatic but may experience odynophagia, retrosternal chest pain or fever (1). Reported cases of disseminated HSV infection in immunocompetent patients are commonly complications of pregnancy (2). However, rare anecdotal case reports describe HSV viremia, proctocolitis and hemorrhagic cystitis in patients with diabetes mellitus (3-5).

The standard gastrointestinal pathology literature describes HSV infection as a localized phenomenon confined to the epithelial tissue circumscribing ulcers (6). However, few studies describe typical findings of disseminated HSV and its tropism within the gastrointestinal tract.

We report a case of disseminated HSV infection of the lung that also complicated ischemic adhesive band disease of the ileum. This patient was predisposed to disseminated HSV infection due to several autoimmune illnesses: type I diabetes, hypothyroidism and celiac disease. HSV cytopathic effect was identified histologically in the ileum mucosal ulcer bed and serosal cellular exudates. Immunohistochemistry (IHC), in situ hybridization (ISH) and conventional and real-time polymerase chain reaction (PCR) confirmed a HSV type II infection.
HSV cytopathic atypia and HSV IHC staining was confined to myofibrocytes and mesothelial cells without involvement of epithelium. HSV was isolated in bronchial secretions postoperatively by direct fluorescence antibodies. To our knowledge, this is the first documentation of the distribution of HSV cytopathic changes in the ileum of a patient with symptomatic disseminated HSV infection complicating type I diabetes. Our case portends that disseminated HSV infection can have a viral cytotropism differing from that of a localized epithelial HSV gastrointestinal tract infection.

\section{CASE PRESENTATION}

A 53-year-old Caucasian woman with chronic type I insulindependent diabetes, hypothyroidism and hypertension developed clinical and radiological features of a small bowel obstruction. A diagnosis of celiac disease was established on endoscopic biopsy five months before her latest hospital admission. She responded rapidly to a gluten-free diet and upon admission denied symptoms that could be attributed to celiac disease. She had been diagnosed with hypothyroidism several years previously and was asymptomatic on adequate thyroid replacement therapy. She had a history of oral cold sores and human papilloma virus cervical dysplasia. Medications included clopidogrel $75 \mathrm{mg}$ per day,

Departments of ${ }^{1}$ Pathology and Laboratory Medicine; ${ }^{2}$ Internal Medicine, Peter Lougheed and Foothills Medical Centres, Calgary, Alberta Correspondence and reprints: Dr SAC Medlicott, Calgary Laboratory Services, Peter Lougheed Centre, 3500 - 26 th Avenue Northeast, Calgary,

Alberta T1Y 6J4. Telephone 403-943-4907, fax 403-291-2931, e-mail shaun.medlicott@cls.ab.ca

Received for publication December 7, 2004. Accepted March 28, 2005 
insulin (neutral protamine Hagedorn: $16 \mathrm{U}$ every morning and $14 \mathrm{U}$ every night; Humulin-R [Eli Lilly Canada Inc]: $8 \mathrm{U}$ to $15 \mathrm{U}$ every morning and $8 \mathrm{U}$ to $14 \mathrm{U}$ every night) and losartan $25 \mathrm{mg}$ per day. Her past surgical history was significant for resection of an ovarian fibroma, an iliac vein thrombectomy, caesarian section and appendectomy.

One week before admission, she was diagnosed with bronchitis and treated with an oral antibiotic. She subsequently developed nausea, vomiting, bloating, abdominal distension and tenderness. She was admitted to the surgical unit for a small bowel obstruction that was confirmed radiologically.

Laparotomy identified right lower quadrant adhesive band disease. The ileum had perforated at a congested and strictured segment that was tightly applied to peritoneal adhesive bands. An end-to-end primary anastomosis was performed.

She remained febrile postoperatively despite receiving piperacillin and Tazocin (Wyeth, Canada) $3.375 \mathrm{~g}$ intravenously every $6 \mathrm{~h}$. Hypoxic respiratory failure developed on day 2 postsurgery. She was transferred to the intensive care unit with presumptive adult respiratory distress syndrome, intubated and ventilated. Confirmation of HSV overgrowth at the bowel perforation site (by histology, IHC, ISH and PCR) and in bronchial secretions (direct fluorescence antibody) prompted intravenous acyclovir therapy. She defervesced two days later with improvement of hypoxia and the radiological pulmonary infiltrates. At no time were mucocutaneous vesicles identified in oral, genital or perianal sites. A negative lumbar puncture excluded encephalitis. Serology was negative for HIV and immunoglobulin subsets were normal. She had a complicated course and care was withdrawn 23 days after admission.

\section{METHODS}

\section{IHC}

Antibodies studied were polyclonal rabbit anticalretinin (PAD:DC8, Zymed Lab Inc, USA; 1:100 dilution); rabbit antiHSV type II (1:100); rabbit anti-HSV type I (1:500); monoclonal mouse anticytomegalovirus (CMV) clone CCH2 (1:500); monoclonal mouse antihuman CD68 clone KP1 (Dako, Denmark A/S; 1:400); monoclonal mouse anti-CD31 JC/70A (Cell Marque, USA; 1:1000); and monoclonal mouse antileukocyte common antigen clone MEM28 (Zymed; 1:800). Immunostaining employed the Envision antimouse and antirabbit antibody and the diaminobenzidine-Plus kit (Dako). Positive controls were run in parallel with test material.

\section{In situ hybridization}

Dewaxed and dehydrated sections were digested with $100 \mu \mathrm{L}$ of pepsin (Carezyme II, Biocare Medical, USA) at $37^{\circ} \mathrm{C}$ for $5 \mathrm{~min}$. Slides were rinsed in Tris-buffered saline, dehydrated in ethanol and air dried. Ten microlitres to $20 \mu \mathrm{L}$ of biotin-labelled HSV type I, HSV type II, CMV and adenovirus probes (ENZOLife Sciences Inc, USA) were placed on slides and cover slipped. The sections with probes were denatured at $95^{\circ} \mathrm{C}$ for $5 \mathrm{~min}$ and the slides incubated at $37^{\circ} \mathrm{C}$ overnight. After hybridization, slides were washed in Tris-buffered saline until the cover slips detached. Digoxigenin-labelled hybrids were then identifiable by the ENZO detection kit (ENZOLife Sciences Inc). The slides were then counterstained with hematoxylin and cover slipped.

\section{PCR}

DNA was extracted from histological slide bowel tissue and amplified by 40 cycles (approximately $2.5 \mathrm{~h}$ ) according to a standard protocol (7). Amplified DNA was analyzed by gel electrophoresis for expected size products. Appropriate DNA was then exposed to dot blot testing to confirm the correct DNA sequencing. Material was tested against CMV primers (HSV [91]-P1 [5'] and HSV [91]-P2 [3']), and varicella zoster virus (VZV) primers (VZV-P1 [5'] and VZV-P2 [3']) (7). Positive HSV sequences are 474 base pairs versus 241 base pairs for VZV (7). All specimens were also analyzed for genes p 27 and p21 to quantitate the DNA and screen for PCR inhibitors.

Real-time (light cycler) PCR used DNA extracted from paraffin blocks according to the QIAamp DNA Mini Kit (Qiagen, Canada) recommendations. Extracted DNA was tested on the LightCycler employing the LightCycler HSV 1/2 Detection Kit (Roche Diagnostics, Canada) and its recommended parameters. Melting curve data were generated and analyzed by the LightCycler software.

\section{RESULTS}

The laboratory received an $11.2 \mathrm{~cm}$ bowel segment fixed in a "U-shape" due to serosal adhesions. A central stenosed region had a transverse $2.4 \mathrm{~cm}$ defect with exudates coating adjacent serosa. Mucosal tissue surrounding the defect was congested. The impression was one of infarction and perforation of an externally compressed segment of small bowel.

Histological assessment revealed a nondescript mucosal ulcer with a granulation tissue base and overlying cellular exudates. Ulcer borders were sharply delineated by intact mucosa. The ulceration extended into the muscularis propria and its focal attenuation was the perforation site. Acute serositis was demonstrated by prominent purulent exudates coating reactive mesothelium.

High power examination of the submucosal ulcer bed delineated rare spindle shaped cells with a ground glass nuclear appearance, circumscribed by a rim of dense chromatin. These cells also had irregular nuclear membranes and were occasionally multinucleated. Similar cytopathic atypia was in the vicinity of the serosa beneath the ulcer. No viral atypia was detected in endothelial cells or mucosal epithelium.

Cells with viral cytopathic effect in the ulcer bed had a HSV type I, HSV type II, vimentin and a focally actin-positive IHC phenotype. Such cells were negative for CMV, CD1a, CD68, CD45, CD20, CD31, S-100 and PGP9.5. Serosal cells with viral inclusions were HSV type I-, HSV type IIand calretinin-positive. These cells were also negative for those antigens that ulcer bed cells failed to react with.

ISH and PCR detected HSV DNA with a melting point characteristic of HSV type II (Figure 1). No CMV, adenovirus or VZV genetic material were detected.

\section{DISCUSSION}

HSV infection of adulthood is predominantly a disease of the immunocompromised (8). In the bone marrow transplant population, $70 \%$ of seropositive patients will reactivate, usually within the first month (8). These patients commonly have oral/genital mucositis with or without esophagitis (9). The rare patient develops HSV dissemination, primarily manifesting as encephalitis, pneumonia or hepatitis (8).

Individuals with substandard immunity (pregnancy and newborns) have a greater propensity for HSV-related illnesses (10-12). Anecdotal cases of HSV viremia, proctocolitis and hemorrhagic cystitis have also been described in patients with diabetes mellitus (3-5). 
HSV infection in immunocompetent patients is usually a localized mucocutaneous or neural ganglia disease (13). However, data suggest that subclinical dissemination may be common. Acute HSV infection of genitalia is associated with a mild elevation of aminotransferases in $14 \%$ of otherwise healthy adults (14). HSV DNA has been isolated in the serum of $20 \%$ of healthy adults experiencing recurrent herpes labialis (15).

The origin of disseminated HSV infection is presumably an extension of oral/genital mucositis or reactivation of neural ganglia latent virus (3). It is postulated that isolated visceral HSV disease may be related to: a large viral load at the time of primary exposure; subtle host $\mathrm{T}$ cell/macrophage deficiencies; reinfection by a second strain; and/or existence of viscerotropic strains (16).

Gastrointestinal HSV infection is primarily an esophagitis, but proctitis is common as a sexually transmitted illness $(17-19)$. HSV infection is usually restricted to the anorectum in the homosexual population, but rare examples of fulminant left-sided colitis have been identified $(20,21)$. Of the 10 reported cases of HSV enteritis/colitis diagnosed antemortem, seven subjects were immunocompromised or on immunosuppressive therapy $(9,21-26)$. One of the remaining three had type IIb diabetes mellitus as a predisposing condition (4). One patient had confirmed Epstein-Barr virus pharyngitis and another had undergone colon carcinoma resection two months previously $(20,27)$. Our patient is the second reported case of herpes enteritis/colitis complicating diabetes mellitus (Table 1).

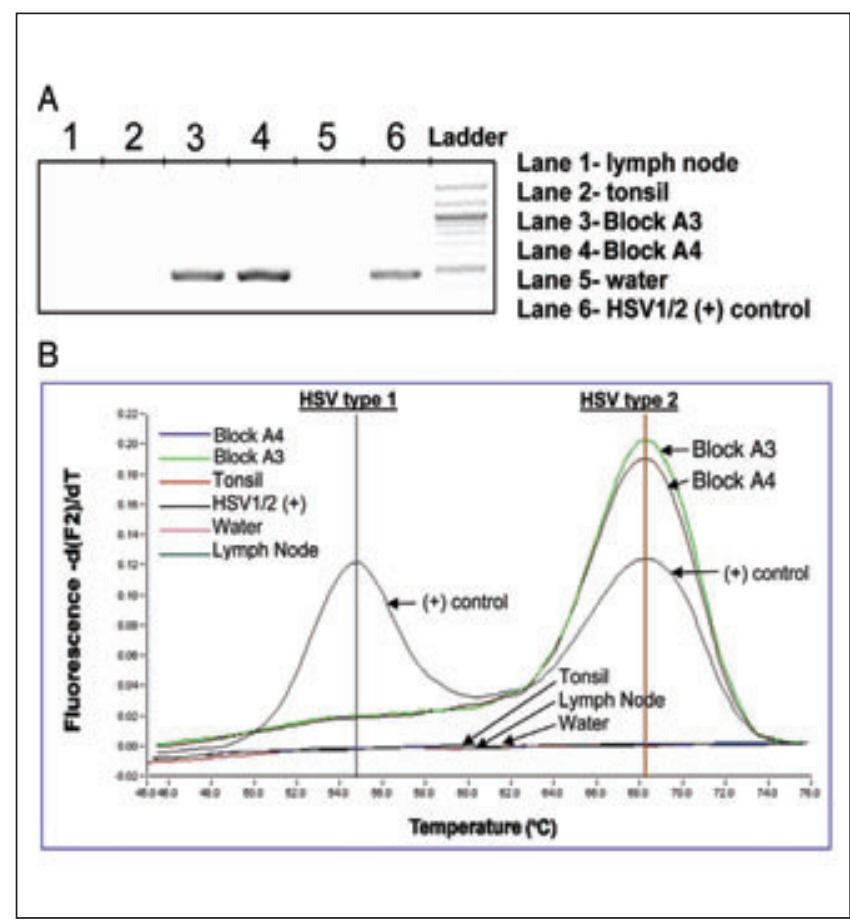

Figure 1) Polymerase chain reaction identifies herpes simplex virus (HSV) DNA in the bowel (two separate paraffin blocks, A3 and A4) and real-time polymerase chain reaction delineates its melting point to be that of HSV type II

TABLE 1

Cases of antemortem herpes simplex virus (HSV) enteritis/colitis published in the English literature

\begin{tabular}{|c|c|c|c|c|c|c|c|c|}
\hline Reference & $\begin{array}{l}\text { Age I } \\
\text { sex }\end{array}$ & Predisposition & $\begin{array}{l}\text { Signs and } \\
\text { symptoms }\end{array}$ & $\begin{array}{l}\text { Other viral } \\
\text { manifestations }\end{array}$ & $\begin{array}{l}\text { Site of } \\
\text { GI HSV }\end{array}$ & $\begin{array}{c}\text { Gross } \\
\text { appearance } \\
\text { of GI tissue }\end{array}$ & $\begin{array}{c}\text { HSV } \\
\text { cytopathic } \\
\text { features }\end{array}$ & Outcome \\
\hline $\begin{array}{l}\text { Wasselle et al } \\
\text { (23) }\end{array}$ & $77 \mathrm{M}$ & $\begin{array}{l}\text { Pure red cell } \\
\text { aplasia, } \\
\text { corticosteroids }\end{array}$ & $\begin{array}{l}\text { Abdominal pain, } \\
\text { diarrhea }\end{array}$ & None & Jejunum & $\begin{array}{l}15 \text { punctuate } \\
\text { ulcers }(0.2 \mathrm{~cm} \text { to } \\
0.4 \mathrm{~cm} \text { in diameter })\end{array}$ & $\begin{array}{l}\text { Histology- and } \\
\text { IHC-positive } \\
\text { (HSV type I and } \\
\text { type II) in serosa } \\
\text { exudate }\end{array}$ & $\begin{array}{l}\text { Perforation, } \\
\text { acyclovir, } \\
\text { resolution }\end{array}$ \\
\hline $\begin{array}{l}\text { Kingreen et al } \\
(9)\end{array}$ & $27 \mathrm{~F}$ & $\begin{array}{l}45 \text { days post-BMT, } \\
\text { GVHD, prednisone } \\
(3 \mathrm{mg} / \mathrm{kg})\end{array}$ & Bloody diarrhea & Skin lesions & Jejunum & $\begin{array}{l}\text { Massively } \\
\text { inflamed, friable }\end{array}$ & $\begin{array}{l}\text { Histology-negative, } \\
\text { IHC-positive } \\
\text { (HSV type I and } \\
\text { type II) in ulcer }\end{array}$ & $\begin{array}{l}\text { Death } 7 \text { days } \\
\text { postoperatively }\end{array}$ \\
\hline $\begin{array}{l}\text { Adler et al } \\
(25)\end{array}$ & $53 \mathrm{M}$ & $\begin{array}{l}10 \text { months post- } \\
\text { kidney transplant, } \\
\text { azathioprine }(150 \mathrm{mg}) \\
\text { prednisone }(10 \mathrm{mg})\end{array}$ & $\begin{array}{l}\text { Abdominal pain, } \\
\text { diarrhea, fever }\end{array}$ & $\begin{array}{l}\text { Oral, perianal } \\
\text { lesions }\end{array}$ & Colon & $\begin{array}{l}\text { Erythematous, } \\
\text { friable, large } \\
\text { symmetrical } \\
\text { ulcers }\end{array}$ & $\begin{array}{l}\text { Multinucleated giant } \\
\text { cells in colonic } \\
\text { epithelium }\end{array}$ & $\begin{array}{l}\text { Acyclovir, } \\
\text { resolution }\end{array}$ \\
\hline $\begin{array}{l}\text { Colemont et al } \\
(20)\end{array}$ & $78 \mathrm{~F}$ & $\begin{array}{l}2 \text { months postcolon } \\
\text { cancer resection, } \\
\text { no medications }\end{array}$ & $\begin{array}{l}\text { Abdominal pain, } \\
\text { bloody diarrhea }\end{array}$ & None & Colon & $\begin{array}{l}\text { Friable cecum, } \\
\text { aphthous ulcers, } \\
\text { pseudopolyps, } \\
\text { necrotic ulcers } \\
\text { in transverse } \\
\text { and left colon }\end{array}$ & $\begin{array}{l}\text { Histology-negative, } \\
\text { electron microscopy- } \\
\text { positive, stool culture- } \\
\text { and HSV type I- } \\
\text { positive }\end{array}$ & $\begin{array}{l}\text { Acyclovir, } \\
\text { resolution }\end{array}$ \\
\hline $\begin{array}{l}\text { Guttman et al } \\
(21)\end{array}$ & $36 \mathrm{M}$ & HIV & $\begin{array}{l}\text { Abdominal pain, } \\
\text { diarrhea }\end{array}$ & $\begin{array}{l}\text { Perianal } \\
\text { vesicles }\end{array}$ & Colon & $\begin{array}{l}\text { Multiple } \\
\text { necrotic ulcers } \\
\text { throughout colon }\end{array}$ & $\begin{array}{l}\text { Viral effect in } \\
\text { endothelial/stromal } \\
\text { cells, rectum and } \\
\text { skin biopsy culture } \\
\text { HSV-positive }\end{array}$ & $\begin{array}{l}\text { Toxic } \\
\text { megacolon, } \\
\text { antibiotics, } \\
\text { resolution }\end{array}$ \\
\hline $\begin{array}{l}\text { Naik and } \\
\text { Chandrasekar } \\
\text { (26) }\end{array}$ & $45 \mathrm{M}$ & $\begin{array}{l}\text { BMT, GVHD, } \\
\text { Clostridum difficile } \\
\text { infection }\end{array}$ & $\begin{array}{l}\text { Abdominal pain, } \\
\text { diarrhea }\end{array}$ & Penile ulcers & $\begin{array}{l}\text { Ileum } \\
\text { colon }\end{array}$ & $\begin{array}{l}\text { Friable ileum, small } \\
\text { ulcers in ileocecum } \\
\text { patchy erythema } \\
\text { of entire colon }\end{array}$ & $\begin{array}{l}\text { Histology-negative; } \\
\text { cecum biopsy culture-, } \\
\text { HSV type II- and } \\
\text { CMV-positive }\end{array}$ & $\begin{array}{l}\text { Gancyclovir } \\
\text { resolution }\end{array}$ \\
\hline
\end{tabular}




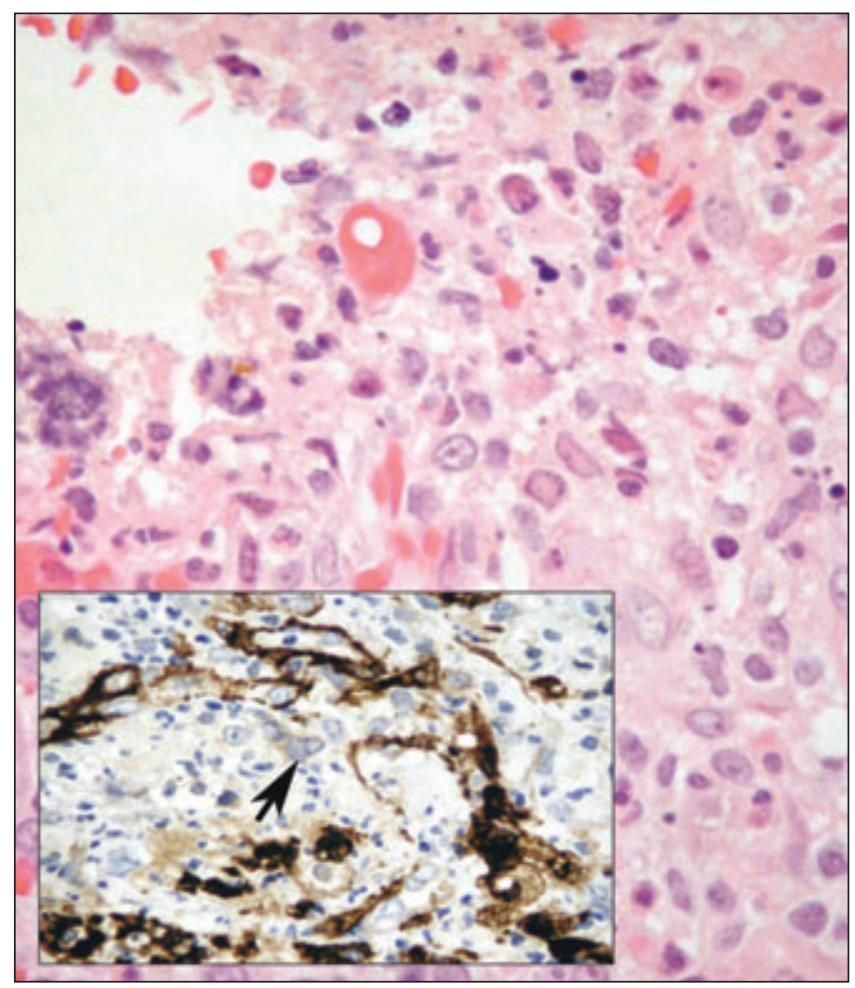

Figure 2) Ileal ulcer bed with herpes simplex virus cytopathic atypia in spindle cells (hematoxylin and eosin, original magnification $\times 40$ ). Inset: actin positivity is in cells with cytopathic change (original magnification $\times 40$ )

HSV enterocolitis manifests as abdominal pain with diarrhea $(20,21,23,25,26)$. Bloody diarrhea and an acute abdomen are less common symptoms $(9,20,27)$. Bowel perforation was identified in three of the 10 reported cases $(23,24,27)$. A slight majority of patients had associated oral/genital mucositis (six of 10) and their symptoms resolved with acyclovir or gancyclovir therapy (six of 10) (9,20-27). Our case of HSV pneumonia complicated by HSV-infected ileal adhesive band disease similarly resolved after surgery and intravenous acyclovir therapy. However, our patient is unique in that bowel symptoms were those of obstruction, indicating that HSV enteritis was a secondary infection of ischemic bowel.

HSV colon infection is classically a diffuse colitis with confluent ulceration (6). Ulcers may be diamond-shaped and most numerous in the sigmoid (6). Five of the 10 reported antemortem cases had a pancolitis $(20-22,25,26)$. However, in one case, ulcers were described as symmetric and possibly diamond shaped. Other descriptions included aphthoid, punctate, stricturing and indurated ulceration in one case each $(4,20,22,23,25)$. Three of 10 patients had perforating ulcers $(23,24,27)$.

Classical histology of HSV infection is multinucleated or single cells having Cowdry type $\mathrm{A}$ inclusions and ground glass nuclear changes. Cowdry type $\mathrm{A}$ bodies are red intranuclear inclusions with a clear halo. Chromatin is relegated to the periphery as a rim of clumped nuclear material. It is commonly regarded that HSV cytopathic atypia is restricted to epithelia, specifically, those cells circumscribing mucosal ulcers (6). This viral effect is typical of primary cutaneous and esophageal lesions.

Of the 10 previously reported antemortem HSV enterocolitis cases, six $(60 \%)$ had viral cytopathic effect identifiable on routine

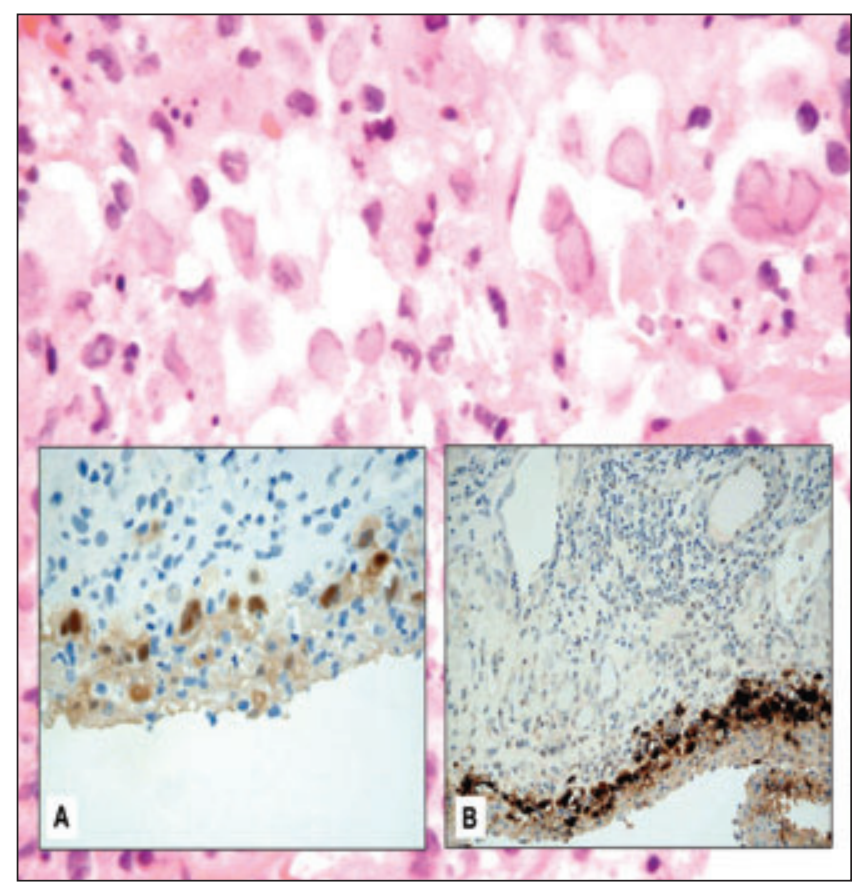

Figure 3) Ileum serosa had a linear band of cells with cytopathic atypia (hematoxylin and eosin, original magnification $\times 40$ ). Calretinin (inset $\mathbf{A}$, original magnification $\times 40$ ) and herpes simplex virus (inset $\mathbf{B}$, original magnification $\times 20$ ) immunohistochemical stains had identical positive linear staining of serosal mesothelium

histological sections $(4,21-23,25,27)$. Specific cells harbouring nuclear atypia included epithelium, endothelium and stromal cells and not otherwise specified $(21,25,27)$. In our case, rare actin- and vimentin-positive myofibrocytes of the ulcer bed had viral cytopathic atypia (Figure 2). Numerous calretinin-positive mesothelial cells also had HSV cytopathic atypia and reacted with HSV IHC antibodies (Figure 3).

To our knowledge, this was the first documentation of HSV type II infecting the mesothelium. This finding was not surprising because other herpes virus subtypes are known to infect mesothelium. Human herpes virus- 8 was identified in mesothelial cells of three of five patients with pleural effusions and Kaposi's sarcoma or Castleman's disease in a recent publication (28).

\section{CONCLUSIONS}

This was a unique case of disseminated HSV type II complicating adhesive band disease. Although HSV type II can disseminate systemically in insulin-dependent diabetes mellitus, this was the first documentation of viral cytopathic atypia in an ileal ulcer bed of such a patient. Previous studies have suggested that HSVinduced cytopathic atypia is generally confined to the intestinal epithelial cells at the perimeter of an ulcer. We report that disseminated HSV type II infects various intestinal cell lineages including myofibrocytes and mesothelium about an ulcer bed, in the absence of intestinal epithelial cell involvement.

ACKNOWLEDGEMENTS: The authors thank Dr Demetrick's laboratory at the University of Calgary, Calgary, Alberta for their expert molecular analysis of the bowel specimen. We would also like to thank Ms Katina Haynes for helping prepare this manuscript for publication. 


\section{REFERENCES}

1. Byard RW, Champion MC, Orizaga M. Variability in the clinical presentation and endoscopic findings of herpetic esophagitis. Endoscopy 1987;19:153-5.

2. Gelven PL, Gruber KK, Swiger FK, Cina SJ, Harley RA. Fatal disseminated herpes simplex in pregnancy with maternal and neonatal death. South Med J 1996;89:732-4.

3. Naraqi S, Jackson GG, Jonasson OM. Viremia with herpes simplex type 1 in adults. Four nonfatal cases, one with features of chicken pox. Ann Intern Med 1976;85:165-9.

4. Tschope D, Niederau C, Erckenbrecht J, Gunther B, Frenzel H, Strohmeyer G. Virus-associated hemorrhagic colitis in the differential diagnosis of periacute rectal bleeding. Dtsch Med Wochenschr 1989;114:58-61.

5. Nguyen ML, Borochovitz D, Thomas G, McClure T, Ruben FL. Hemorrhagic cystitis with herpes simplex virus type 2 in the bladder mucosa. Clin Infect Dis 1992;14:767-8.

6. Fenoglio-Preiser CM, Noffsinger AE, Stemmermann GN, Lantz PE, Listrom MB, Rilke FO. Gastrointestinal Pathology: An Atlas and Text, 2nd edn. Philadelphia-New York: Lippincott-Raven 1999:180,579.

7. Tang YW, Mitchell PS, Espy MJ, Smith TF, Persing DH. Molecular diagnosis of herpes simplex virus infections in the central nervous system. J Clin Microbiol 1999;37:2127-36.

8. Zaia JA. Viral infections associated with bone marrow transplantation. Hematol Oncol Clin North Am 1990;4:603-23.

9. Kingreen D, Nitsche A, Beyer J, Siegert W. Herpes simplex infection of the jejunum occurring in the early post-transplantation period. Bone Marrow Transplant 1997;20:989-91.

10. Hufert FT, Diebold T, Ermisch B, von Laer D, Meyer-Konig U, Neumann-Haefelin D. Liver failure due to disseminated HSV-1 infection in a newborn twin. Scand J Infect Dis 1995;27:627-9.

11. Young E, Chafizadeh E, Oliveira VL, Genta RM. Disseminated herpesvirus infection during pregnancy. Clin Infect Dis 1996;22:51-8.

12. Johnson JR, Egaas S, Gleaves CA, Hackman R, Bowden RA. Hepatitis due to herpes simplex virus in marrow-transplant recipients. Clin Infect Dis 1992;14:38-45.

13. Velasco M, Llamas E, Guijarro-Rojas M, Ruiz-Yague M. Fulminant herpes hepatitis in a healthy adult: A treatable disorder? J Clin Gastroenterol 1999;28:386-9.

14. Minuk GY, Nicolle LE. Genital herpes and hepatitis in healthy young adults. J Med Virol 1986;19:269-75.

15. Brice SL, Stockert SS, Jester JD, Huff JC, Bunker JD, Weston WL. Detection of herpes simplex virus DNA in the peripheral blood during acute recurrent herpes labialis. J Am Acad Dermatol 1992;26:594-8.
16. Miyazaki Y, Akizuki S, Sakaoka H, Yamamoto S, Terao H. Disseminated infection of herpes simplex virus with fulminant hepatitis in a healthy adult. A case report. APMIS 1991;99:1001-7.

17. Shah S, Scholz F. Anorectal herpes: Radiographic findings. Radiology 1983;147:81-2.

18. Goldmeier D. Proctitis and herpes simplex virus in homosexual men. Br J Vener Dis 1980;56:111-4.

19. Goodell S, Quinn T, Mkrtichian E, Schuffler MD, Holmes KK, Corey L. Herpes simplex virus proctitis in homosexual men. Clinical, sigmoidoscopic, and histopathological features. N Engl J Med 1983;308:868-71.

20. Colemont LJ, Pen JH, Pelckmans PA, Degryse HR, Pattyn SR, Van Maercke YM. Herpes simplex virus type 1 colitis: An unusual cause of diarrhea. Am J Gastroenterol 1990;85:1182-5.

21. Guttman D, Raymond A, Gelb A, et al. Virus-associated colitis in homosexual men: Two case reports. Am J Gastroenterol 1983;78:167-9.

22. Ruther U, Nunnensiek C, Muller HA, et al. Herpes simplexassociated exacerbation of Crohn's disease. Successful treatment with acyclovir. Dtsch Med Wochenschr 1992;117:46-50.

23. Wasselle JA, Sedgwick JH, Dawson PJ, Fabri PJ. Intestinal herpes simplex infection presenting with intestinal perforation. Am J Gastroenterol 1992;87:1475-7.

24. Getlik A, Palenikova O, Brix M. Recurrent herpetic gingivostomatitis and enteritis resulting in a perforated intestine in a boy with primary cellular immunodeficiency. Cesk Pediatr 1988;43:493-5.

25. Adler M, Goldman M, Liesnard C, Hardy N, Van Gossum A, Engelholm L. Diffuse herpes simplex virus colitis in a kidney transplant recipient successfully treated with acyclovir. Transplantation 1987;43:919-21.

26. Naik HR, Chandrasekar PH. Herpes simplex virus (HSV) colitis in a bone marrow transplant recipient. Bone Marrow Transplant 1996;17:285-6.

27. Moriuchi H, Yoshida Y, Oshima T. Gut perforation after infection with herpes simplex virus and Epstein-Barr virus. Lancet 1989;2:568.

28. Bryant-Greenwood P, Sorbara L, Filie AC, et al. Infection of mesothelial cells with human herpes virus 8 in human immunodeficiency virus-infected patients with Kaposi's sarcoma, Castleman's disease, and recurrent pleural effusions. Mod Pathol 2003;16:145-53. 


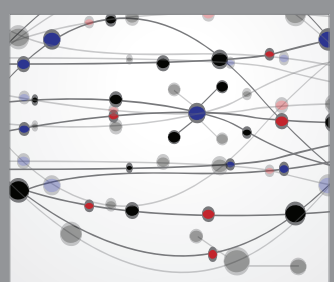

The Scientific World Journal
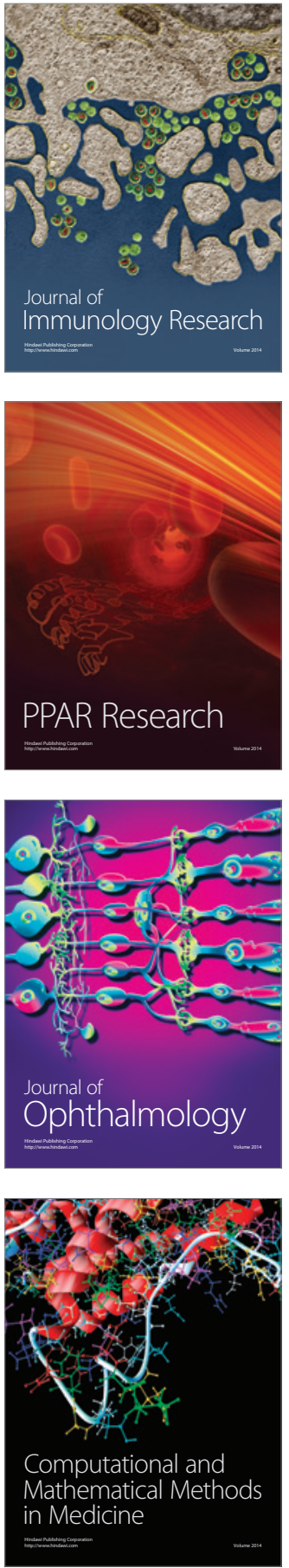

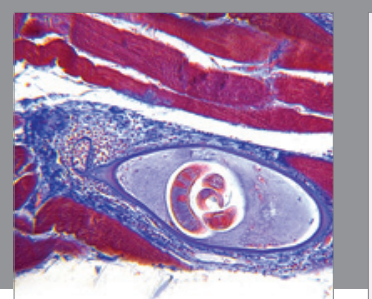

Gastroenterology Research and Practice

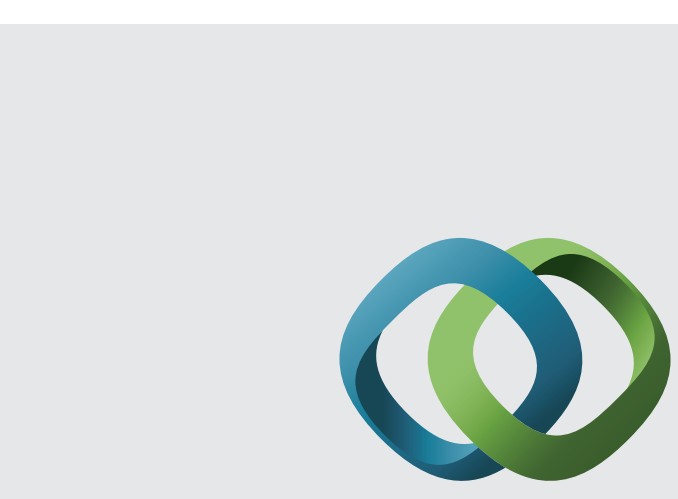

\section{Hindawi}

Submit your manuscripts at

http://www.hindawi.com
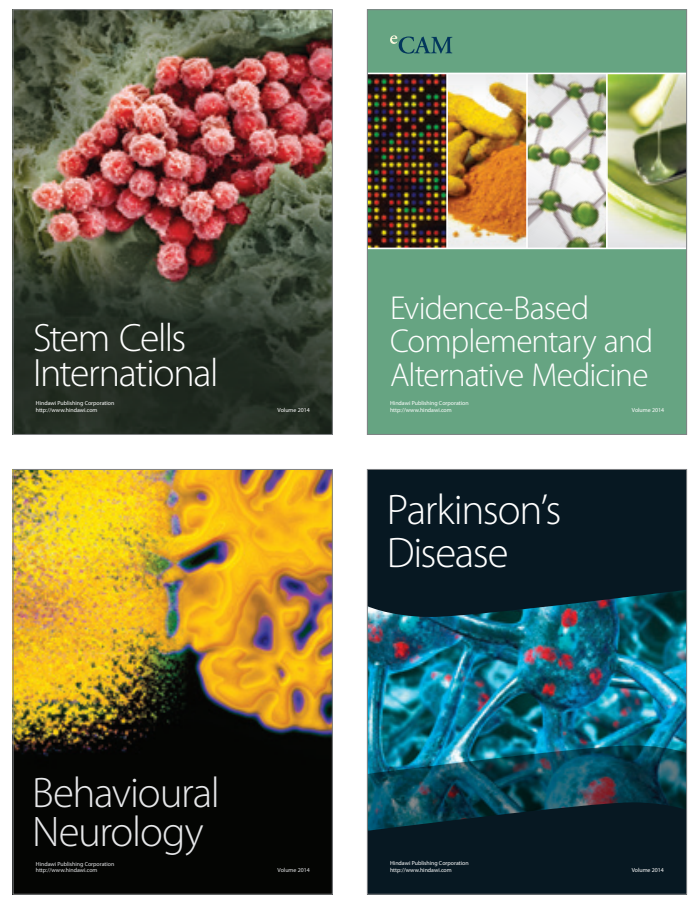
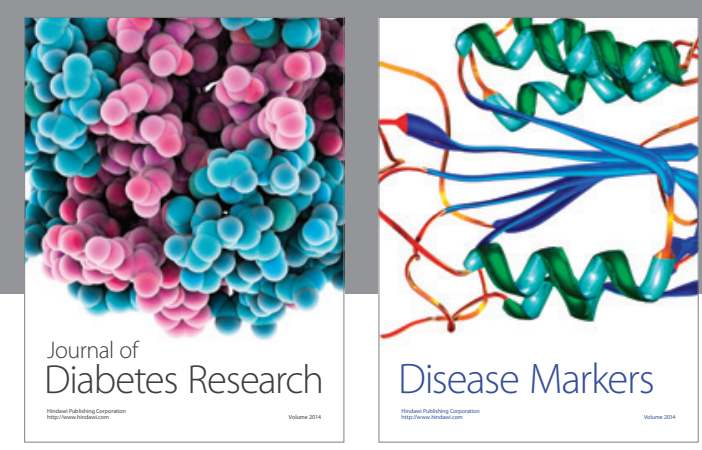

Disease Markers
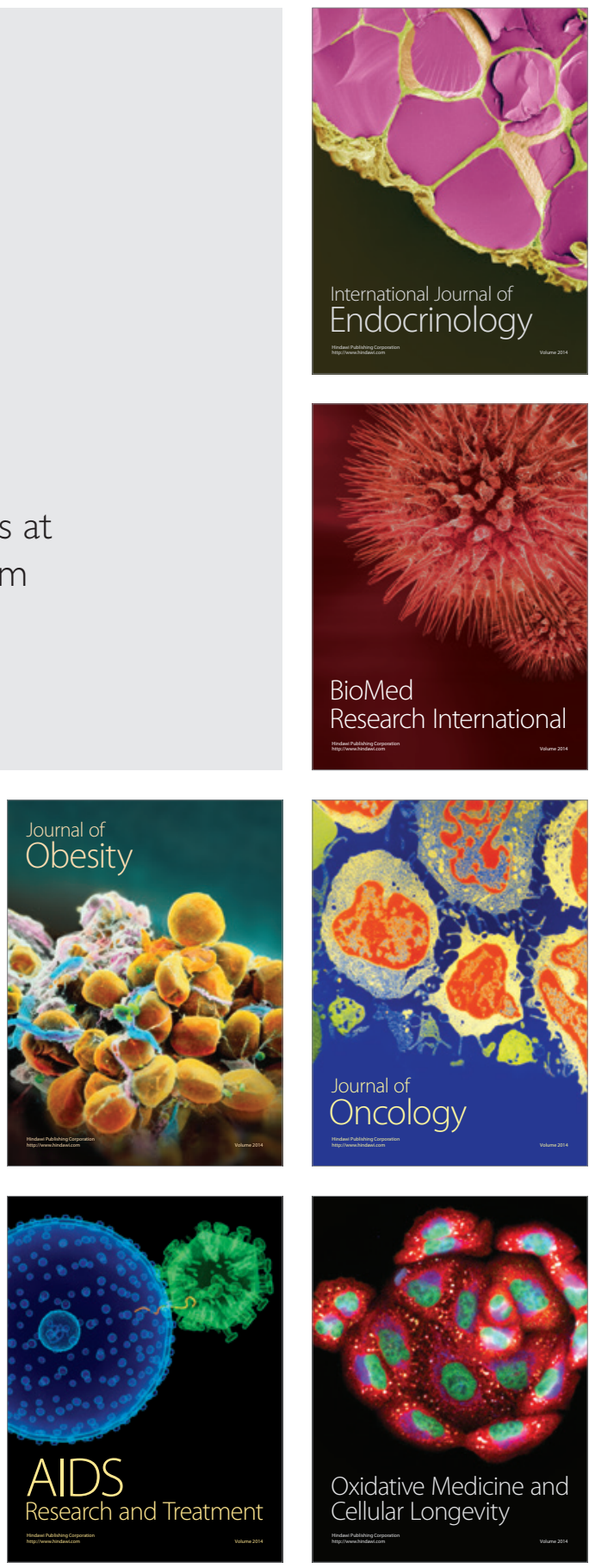